\section{Health in the post-2015 agenda: perspectives midway through}

\author{
Saúde na agenda pós-2015: perspectivas a meio \\ do caminho
}

\author{
Salud en la agenda post-2015: perspectivas a la \\ mitad del camino
}

\footnotetext{
1 Global Health Programme,

Graduate Institute

of International and

Development Studies,

Geneva, Switzerland.

2 Centro de Relações

Internacionais em Saúde,

Fundação Oswaldo Cruz,

Rio de Janeiro, Brasil

Correspondence

P. M. Buss

Centro de Relações

Internacionais em Saúde,

Fundação Oswaldo Cruz.

Av. Brasil 4365, Prédio do

Antigo Almoxarifado Central,

Rio de Janeiro, RJ 21040-900,

Brasil.

buss@fiocruz.br
}

On September 2014, the United Nations General Assembly (UNGA) will evaluate the proposals of the UN Open Working Group (OWG) 1 for the Sustainable Development Goals (SDG) in the Post-2015 Agenda, which also includes a health goal. The final version of these goals will be approved at the 2015 UNGA. The document is the convergence of several processes implemented by the United Nations General Secretariat and the UNGA since the conclusion of the United Nations Conference on Sustainable Development, the Rio+20 Conference, such as the Global Consultation and Dialogue 2 and the High-Level Panel of Eminent Persons 3.

The OWG suggested 17 SDGs (http://sus tainabledevelopment.un.org/focussdgs.html), which address a wide range of issues from the eradication of extreme poverty and hunger to industrialization, sustainable energy, the protection of the environment, education and other social, economic and environmental issues - the three pillars of sustainable development -, as established in the final document of the Rio+20, The Future We Want 4 . Each goal also has "means of implementation".

After long discussions carried out since the Rio+20, the OWG decided to establish the Health SDG as "ensure healthy lives and promote wellbeing for all at all ages", which is much more comprehensive than the "sectoral" proposal of
Ilona Kickbusch 1

Paulo M. Buss ${ }^{2}$

the World Health Organization (WHO), which has been advocating "universal health coverage" as a SDG for Health. This present proposal is much more coherent with the ideas that health is socially produced and that consideration needs to be given to the social determinants of health. It also fits much better with the WHO Constitution of 1948 .

There are 13 targets for the Health SDG (http://sustainabledevelopment.un.org/focuss dgs.html). However, these targets narrow down the broader, initial goal, because they are linked only to individual and curative elements of health care. Fundamental elements of public health, that is, those dedicated to "ensuring health and promoting well-being" and not simply "fighting diseases", were not included: epidemiological, sanitary and environmental surveillance is omitted; health promotion and addressing the social determinants of health are not even mentioned. The goals for implementation are excessively fragmented and uncoordinated with the other SDGs - quite contrary to what would be crucial for the intersectoral governance required to "ensure healthy lives and promote well-being”.

The targets, which we call "issue targets", address health problems in a traditional and fragmented way: maternal and child mortality and communicable diseases (part of the "unfinished agenda of the MDGs"); non-communicable dis- 
eases; mental health; illicit and licit drug abuse; external causes (road traffic); chemical and water, soil and air contamination. All of these are important and they mirror the disease priorities of the WHO but they do not reflect an integrated approach to sustainable development for health.

The "process targets" (which relate to "health governance") address the organization of health systems to tackle problems an important step forward from the "issue" targets: they include universal health coverage (UHC), sexual and reproductive health, the prevention and treatment of drug abuse, essential health care services, access to medicines and vaccines, financing and human resources. Moreover, one of the targets (\#13) can be labeled as "epidemiological surveillance". However, it still omits many aspects of public health, in particular the crucial regulatory action by governments which is frequently required to fulfill all other targets and to protect health. Comprehensive strategies (governance for health) such as fiscal policies to tackle prevalent health priorities as well as addressing the social determinants of health are not considered.

There are sensitive political and technical issues involving the negotiations until 2015. There is little time to intervene and change the course - only one year between the UNGA of 2014 and of 2015. The fierce debates carried out and the agreements reached at the OWG cannot be dismissed, though. However, the fragmentation of the "issue targets", the insufficient and uncoordinated "process targets" (or governance targets), as well as the omission regarding the social determinants of health need to be addressed - both in the health SDG and in the other SDGs. Such cross referencing is critical as health is an indicator, outcome and contributor to sustainable development. One alternative would be adopting one comprehensive health SDG of "developing universal, integral, equitable, high-quality health systems" based on the right to health, and one health SDG that integrates policy making for health and addresses the social determinants of health.

Coherent "means of implementation" need to be developed - such as innovative forms of governance for health that address the social determinants of health, which include the other sec- tors of the government, as well as the civil society. This would be similar to what has been discussed regarding the governance of sustainable development as a whole at the High-Level Political Forum (HLPF) on Sustainable Development (composed by the Heads of State and Government), and working under the title From Silos to Integrated Policy Making 5 which recommends "goes beyond merely 'aggregating' independently formulated policies across the different domains".

These proposals - as well as others that could strengthen the still weak Health SDG and its targets - should be introduced to the foreign ministries and the diplomatic service of countries, which will take the decisions at the 2014 and 2015 UNGA. Other political and technical actors that discuss sustainable development today - like the global academic community (which has been participating little in the discussions and not making its voice sufficiently heard) and the civil society (which has been isolated and has little space due to the current democratic deficit in the global governance structure) - should also be mobilized to highlight the many ways health permeates the challenges the SDGs aim to address.

Another initiative would be suggest to the HLPF to carry out a review of how to best take the central role of health in the SDGs - as an indicator, outcome and contributor to sustainable development - into account. So far this is a missed opportunity to show how the health of people and the health of the planet are inextricably linked. Such a review could explore the governance mechanisms required to meet the health targets of the Health SDG and the healthrelated dimensions in the other SDGs. Part of the governance deficiencies could be resolved with that. Furthermore, the exercise could be used as a model for other issues in the set of suggested SDGs most of which include intersectoral challenges.

The health community must rise to the complex negotiations for the SDGs and respond to their technical and political challenges. It must show how health is integral to inclusive global development and the sustainable future for the planet. After all the effort of the SDGs is the ensure a better life for all in a world we want. 


\section{Contributors}

All the authors participated in all stages of the article's production.

1. UN Open Working Group on Sustainable Development. Outcome document. http://sustainablede velopment.un.org/focussdgs.html.

2. United Nations. Health in the post-2015 agenda: report of the global thematic consultation on health. http://www.worldwewant2015.org/ file/337378/download/366802.

3. United Nations. The report of the high-level panel of eminent persons on the post-2015 development agenda: a new global partnership - eradicate poverty and transform economies through sustainable development. http://www.post2015hlp.org/ wp-content/uploads/2013/05/UN-Report.pdf.
4. United Nations. The future we want. http://sus tainabledevelopment.un.org/futurewewant.html.

5. United Nations. High-Level Political Forum on Sustainbale Development. From silos to integrated policy making. http://sustainabledevelopment. un.org $/$ index.php?page $=$ view\&type $=400 \& n r=1322$ \&menu $=35$.

Submitted on $01 / \mathrm{Sep} / 2014$

Approved on 02/Sep/2014 